\title{
Bioaccumulation kinetics and exposure pathways of inorganic mercury and methylmercury in a marine fish, the sweetlips Plectorhinchus gibbosus
}

\author{
Wen-Xiong Wang*, Raymond S. K. Wong \\ Department of Biology, The Hong Kong University of Science and Technology (HKUST), Clear Water Bay, Kowloon, \\ Hong Kong SAR
}

\begin{abstract}
We experimentally determined the assimilation efficiency (AE) of ingested prey, the uptake-rate constant from the aqueous phase, and elimination-rate constant of both inorganic $\mathrm{Hg}(\mathrm{Hg}[\mathrm{II}])$ and methylmercury (MeHg) in a marine predatory fish, the sweetlips Plectorhinchus gibbosus, using radiotracer techniques. The $\mathrm{AE}$ of $\mathrm{Hg}$ (II) and $\mathrm{MeHg}$ ranged between 10 and $27 \%$ and between 56 and $95 \%$, respectively, for 3 different prey (copepods, silverside, and brine shrimp). The ingestion rate of the fish did not significantly affect the $\mathrm{AE}$ of $\mathrm{Hg}(\mathrm{II})$. Uptake of both species of $\mathrm{Hg}$ proceeded in a linear pattern, and the calculated uptake-rate constant was 0.195 and $4.515 \mathrm{~g}^{-1} \mathrm{~d}^{-1}$ for $\mathrm{Hg}$ (II) and $\mathrm{MeHg}$, respectively. Most of the accumulated Hg(II) was distributed in muscle tissues, whereas the accumulated $\mathrm{MeHg}$ was distributed evenly between gills and muscle tissues. The calculated elimination-rate constants for $\mathrm{MeHg}$ were 0.0103 and $0.0129 \mathrm{~d}^{-1}$ following dietary and aqueous uptake, respectively, whereas the elimination-rate constant of $\mathrm{Hg}$ (II) following dietary uptake $\left(0.0547 \mathrm{~d}^{-1}\right)$ was 1.9 times higher than the elimination following aqueous uptake $\left(0.0287 \mathrm{~d}^{-1}\right)$. These experimentally determined values were incorporated into a kinetic model to predict the exposure pathways and the relative contribution of $\mathrm{Hg}$ (II) and $\mathrm{MeHg}$ to the sweetlips. At the high end of the bioconcentration factor for both species of $\mathrm{Hg}$ in the prey, dietary ingestion is likely to be the main channel for their accumulation in the fish. The relative contribution of $\mathrm{Hg}$ (II) vs $\mathrm{MeHg}$ to the overall $\mathrm{Hg}$ bioaccumulation is largely controlled by the relative concentration of $\mathrm{MeHg}$ dissolved in seawater. Similar to the results of numerous field studies, the kinetic model predicted a potential trophic transfer factor of $<0.6$ for $\mathrm{Hg}$ (II) and $>1$ for $\mathrm{MeHg}$ under conditions likely to be experienced by the fish in its natural environment.
\end{abstract}

KEY WORDS: Mercury $\cdot$ Methylmercury $\cdot$ Exposure $\cdot$ Fish $\cdot$ Kinetic modeling

Resale or republication not permitted without written consent of the publisher

\section{INTRODUCTION}

Concern about mercury $(\mathrm{Hg})$ in marine food webs is mainly related to the biomagnification of methylmercury $(\mathrm{MeHg})$ with increasing trophic levels (Monteiro et al. 1996, Boudou \& Ribeyre 1997, Bargagli et al. 1998, Jackson 1998, Mason 2002, Wang 2002). There are numerous examples of the biomagnification of $\mathrm{MeHg}$ toward the upper end of the marine food chain, raising considerable concern about potential human exposure through seafood consumption. In Hong Kong, some reports have pointed to the possible links between local human male subfertility and the con- sumption of seafood containing $\mathrm{Hg}$ (Dickman et al. 1998, 1999). There is now substantial concern about the potential human parental transfer of mercury in Hong Kong, because fishes comprise the major seafood in the region. Understanding the bioaccumulation and bioavailability of different $\mathrm{Hg}$ species in marine fishes can thus aid the prediction of the environmental fate of $\mathrm{Hg}$ (Morel et al. 1998) and realistic risk-assessment of $\mathrm{Hg}$ exposure and toxicity. Many studies have examined the bioaccumulation of inorganic $\mathrm{Hg}[\mathrm{Hg}(\mathrm{II})]$ and $\mathrm{MeHg}$ in freshwater fishes (Boudou \& Ribeyre 1984, 1997, Ribeyre \& Boudou 1984, Boudou et al. 1991, Jackson 1998, Bowles et al. 2001). The biokinetics and 
bioavailability of these $\mathrm{Hg}$ species in marine fishes are less well studied (Pentreath 1976a,b, Honda et al. 1978, Barkay et al. 1997, Rouleau et al. 1998).

Most previous studies measured the concentration of different $\mathrm{Hg}$ species in different tissues of fishes (Leah et al. 1991, Monteiro et al. 1996, Joiris et al. 2000). The routes of $\mathrm{Hg}$ accumulation, including the relative importance of different $\mathrm{Hg}$ species (inorganic and organic) and exposure pathways (aqueous vs dietary), are not yet well understood. Whereas it has generally been assumed that fishes accumulate $\mathrm{MeHg}$ mainly from dietary sources through very efficient assimilation of this compound (Mason 2002), it is quite possible that, because of its highly efficient absorption properties, they accumulate it from the aqueous phase also. Experimental studies on the routes of methylmercury exposure in fishes are indeed rather controversial (Honda et al. 1978, Phillips \& Buhler 1978, Fujiki 1980, Hall et al. 1997). Kinetic modeling now offers a powerful approach for delineating the exposure of different metal species and pathways (Wang et al. 1997, 1998, Wang \& Fisher 1999). Within the framework of the kinetic model, however, some important parameters need to be quantified, including the assimilation efficiency from the ingested prey, the uptake-rate constant from the aqueous phase, and the elimination-rate constant, as well as some physiological and geochemical parameters such as the feeding rate of the animals and the concentrations of metals in the water and in the dietary sources. Although the biokinetic parameters of metals have been extensively quantified in several species of marine animals, many of these parameters are not yet available for marine fishes (Baines et al. 2002, Xu \& Wang 2002).

The relative importance of $\mathrm{Hg}(\mathrm{II})$ and $\mathrm{MeHg}$ in the overall $\mathrm{Hg}$ bioaccumulation in fishes has been little studied. Whereas numerous studies have demonstrated that $\mathrm{MeHg}$ is the predominant $\mathrm{Hg}$ form (Bowles et al. 2001, Kannan et al. 1998) in fish muscle, it is not known whether it is directly accumulated from the ambient environment (including both aqueous and dietary sources) or is methylated within the fish body. In natural oxic water, the proportion of $\mathrm{MeHg}$ in the total $\mathrm{Hg}$ concentration is generally very low (Fitzgerald \& Mason 1997, Watras et al. 1998); thus, whether $\mathrm{MeHg}$ can contribute considerably to the overall $\mathrm{Hg}$ bioaccumulation in fishes is a matter of speculation. The speciation of $\mathrm{Hg}$ in other fish tissues (e.g. gills, brains, viscera) has not been extensively quantified. There is some evidence of considerable methylation and demethylation in fish muscle (Burrows \& Krenkel 1973, Simon \& Boudou 2001), although some studies have also indicated that fishes are unlikely to methylate the inorganic $\mathrm{Hg}$ to $\mathrm{MeHg}$ within their tissues in vivo (Pennacchioni et al. 1976).
In this study, we examined the biokinetics of both $\mathrm{Hg}$ (II) and $\mathrm{MeHg}$ in a marine predatory fish (the sweetlips Plectorhinchus gibbosus) during both the aqueous and dietary phases. Sweetlips is important fish species widely cultured in China, and is used either as fish food or for direct human consumption. We measured a few kinetic parameters (assimilation efficiency, aqueous uptake-rate, and elimination-rate) of both $\mathrm{Hg}$ species in the fish. A simple kinetic model (Thomann 1981) was then constructed to predict the trophic transfer factor of $\mathrm{Hg}$ and the exposure pathways of both $\mathrm{Hg}$ species in the fish under different environmental conditions. Despite the considerable ecological interest in the trophic transfer of mercury in marine food chains, the exposure pathways and the relative importance of different mercury species in mercury bioaccumulation in marine animals are not well known. Such information is critical for the assessment of the environmental fate of mercury in marine ecosystems as well as for determining the transfer of mercury in marine planktonic food chains.

\section{MATERIALS AND METHODS}

Fish and radioisotopes. Marine sweetlips Plectorhinchus gibbosus ( 3.0 to $3.5 \mathrm{~cm}$ ) were purchased from a fish farm in Hong Kong, and were maintained in aerated artificial seawater (Instant Ocean ${ }^{\circledR} ; 23^{\circ} \mathrm{C}, 30 \mathrm{psu}$ ) and fed fresh clam and/or frozen shrimp (obtained from a local supermarket) twice a day. All experiments were performed at this temperature and salinity. The uptake and elimination by the fish were studied using radiotracers: ${ }^{203} \mathrm{Hg}(\mathrm{II})\left(t_{1 / 2}=46.9 \mathrm{~d}\right.$, in $0.1 \mathrm{~N} \mathrm{HCl}$, specific activity $=10.8 \mathrm{GBq} \mathrm{g}^{-1}$; purchased from Riso National Laboratory, Denmark) and $\mathrm{Me}^{203} \mathrm{Hg}$. $\mathrm{Me}^{203} \mathrm{Hg}$ was synthesized from ${ }^{203} \mathrm{Hg}$ (II) using a wellestablished method (Rouleau \& Block 1997). Radioactivity of ${ }^{203} \mathrm{Hg}$ (II) and $\mathrm{Me}^{203} \mathrm{Hg}$ was measured by a gamma counter at $279 \mathrm{keV}$, and was corrected for counting efficiency and geometry.

Assimilation efficiency (AE). The $A E$ of ${ }^{203} \mathrm{Hg}$ (II) and $\mathrm{Me}^{203} \mathrm{Hg}$ were measured using the pulse-chase technique, described in $\mathrm{Ni}$ et al. (2000) and $\mathrm{Xu} \&$ Wang (2002). Experiments were conducted to quantify the $A E$ in fish feeding on 3 different prey and at different densities of copepod prey. In the prey-type experiment, 3 prey diets were used: the brine shrimp Artemia sp. (hatched under laboratory conditions for $1 \mathrm{~d}$ ), the copepod Acartia spinicauda (collected from Port Shelter, Hong Kong), and small fish (silverside Atherion elymus collected from Port Shelter, Hong Kong: tissues only were used). The brine shrimp were radiolabeled with ${ }^{203} \mathrm{Hg}$ (II) and $\mathrm{Me}^{203} \mathrm{Hg}$, respectively, in $200 \mathrm{ml} 0.22 \mu \mathrm{m}$ filtered seawater. Radioactivity additions were 3.7 and 
$1.85 \mathrm{kBq}$ for ${ }^{203} \mathrm{Hg}(\mathrm{II})$ and $\mathrm{Me}^{203} \mathrm{Hg}$, respectively. The fish prey were radiolabeled in $1.5 \mathrm{l}$ filtered seawater spiked with 3.7 and $1.85 \mathrm{kBq}$ for ${ }^{203} \mathrm{Hg}$ (II) and $\mathrm{Me}^{203} \mathrm{Hg}$, respectively. The copepods were radiolabeled in $400 \mathrm{ml}$ filtered seawater spiked with 3.7 and $7.4 \mathrm{kBq}$ of ${ }^{203} \mathrm{Hg}(\mathrm{II})$ and $\mathrm{Me}^{203} \mathrm{Hg}$, respectively. After $36 \mathrm{~h}$ exposure to radiotracers, the prey (copepods and brine shrimp) were removed from their exposure medium, rinsed thoroughly with seawater, and fed to the fish naturally. The silverside prey was dissected, and only the muscle tissues were fed to the sweetlips naturally. The radioactive pulse feeding lasted $60 \mathrm{~min}$, during which no radioactive feces were produced. There were 5 replicate individuals in each treatment. After the radioactive feeding, the fish were placed in nonradioactive water (10 l) and depurated of their ingested metals for $48 \mathrm{~h}$. The radioactivity remaining in the fish was quantified non-destructively at $3,6,12,18,24,36$, and $48 \mathrm{~h}$. Water was renewed every $12 \mathrm{~h}$ to ensure that the amount of radioactivity in the water was negligible within the $48 \mathrm{~h}$ depuration period. The fish were fed with nonradioactive shrimp meat twice a day during the depuration period. The $A E$ was calculated as the percentage of metal retained in the fish at $24 \mathrm{~h}$.

In the prey-density experiment, the copepods were radiolabeled by exposure to $7.4 \mathrm{kBq}$ of ${ }^{203} \mathrm{Hg}$ (II) in $400 \mathrm{ml}$ filtered seawater for $36 \mathrm{~h}$. Considering the very efficient assimilation by the fish [see 'Results'], we did not examine the influence of prey density on the AE of $\mathrm{MeHg})$. The prey was then rinsed and fed to the fish at different densities for $30 \mathrm{~min}$ : 50, 100, 500, 1000 individuals $\mathrm{l}^{-1}$. There were 4 to 5 individual fish in each treatment. Prey was added every 10 min to maintain a constant density. After feeding, the radioactivity of each individual fish was immediately measured. A subsample of copepod prey remaining in the feeding beakers was collected and the number of copepods as well as the amount of ${ }^{203} \mathrm{Hg}$ (II) radioactivity were counted and measured. The ingestion rate of each individual fish was calculated by dividing the total amount of radioactivity ingested (measured by gamma counting) by the radioactivity of each individual copepod. The fish were subsequently returned to nonradioactive water and allowed to depurate the ingested food materials for a period of $48 \mathrm{~h}$. Shrimp meat was fed to the fish during the depuration period, and the seawater was changed every $12 \mathrm{~h}$. Feces produced during the depuration period were removed every $8 \mathrm{~h}$. At the end of the experiment, the fish were dried at $90^{\circ} \mathrm{C}$ overnight, and their dry weight measured. Ingestion rate was expressed as a percentage of the dry weight on a daily basis.

${ }^{203} \mathrm{Hg}(\mathrm{II})$ and $\mathrm{Me}^{203} \mathrm{Hg}$ uptake from dissolved phase. Preliminary experiments suggested that the fish exhibited a linear pattern of uptake over a $24 \mathrm{~h}$ exposure period. We thus used a shorter term of exposure $(4 \mathrm{~h})$ to quantify mercury unidirectional flux into the fish, in order to avoid a decline in radioactivity in the exposure medium as well as to maintain optimum conditions for the fish. ${ }^{203} \mathrm{Hg}$ (II) and $\mathrm{Me}^{203} \mathrm{Hg}$ uptake by the fish was studied at different dissolved concentrations. No stable $\mathrm{Hg}$ was added to the water, thus different concentrations were achieved by addition of ${ }^{203} \mathrm{Hg}$ (II) and $\mathrm{Me}^{203} \mathrm{Hg}$ of different radioactivities. The concentrations of $\mathrm{Hg}(\mathrm{II})$ resulting from radioisotope addition were $0.109,0.421,2.105,10.90 \mu \mathrm{g} \mathrm{l}^{-1}$, and those of MeHg were $0.020,0.105,0.361,1.832 \mu g \mathrm{l}^{-1}$. Higher concentrations than background concentrations were employed because of the availability of the ${ }^{203} \mathrm{Hg}$ isotope with a relatively low specific activity (including carrier). The radioisotopes were equilibrated with the seawater for $8 \mathrm{~h}$ before the uptake measurements. We placed 5 replicate fish in $1.5 \mathrm{l}$ of $0.22 \mu \mathrm{m}$ filtered seawater containing the radioisotopes. At 1, 2, 3, and $4 \mathrm{~h}$ exposure, the fish were removed from the radioactive medium and transferred to another beaker containing filtered non-radioactive water to remove weakly bound radioisotopes. The radioactivity of the fish was then measured non-destructively using a gamma detector. A seawater sample was also taken, and its radioactivity was measured at each time point. The exposed seawater was renewed after $2 \mathrm{~h}$ of exposure. In general, the decrease of radioactivity in the medium due to uptake by the fish was negligible for ${ }^{203} \mathrm{Hg}(\mathrm{II})$, and $<27 \%$ for $\mathrm{Me}^{203} \mathrm{Hg}$ within the first $2 \mathrm{~h}$ of exposure. After the radioactivity measurement, the fish were returned to the exposure medium. After a further $4 \mathrm{~h}$ exposure, the fish were dissected into 3 body parts: gills, viscera, and the remainder of the tissues, including bones (hereafter referred to as 'tissues'). The radioactivity of each body part was measured. The fish were then dried at $90^{\circ} \mathrm{C}$ for $>1 \mathrm{~d}$ and their dry weights were measured.

The dry weight concentration factor $\left(\mathrm{DCF}, 1 \mathrm{~kg}^{-1}\right)$ of both ${ }^{203} \mathrm{Hg}(\mathrm{II})$ and $\mathrm{Me}^{203} \mathrm{Hg}$ was calculated as the ratio of the radioactivity in the fish (counts $\mathrm{min}^{-1} \mathrm{~kg}^{-1}$ ) to the radioactivity in the water $\left(\mathrm{cpm} \mathrm{l}^{-1}\right.$, calculated as the mean before and after exposure for each time point). The uptake-rate was calculated as the slope of the linear regression between the DCF and the time of exposure multiplied by the dissolved $\mathrm{Hg}$ concentrations.

${ }^{203} \mathrm{Hg}$ (II) and $\mathrm{Me}^{203} \mathrm{Hg}$ elimination after aqueous and dietary exposure. Fish were exposed to ${ }^{203} \mathrm{Hg}$ (II) and $\mathrm{Me}^{203} \mathrm{Hg}$ in the aqueous phase or the dietary phase. In the aqueous exposure, 10 individual fish were exposed to dissolved ${ }^{203} \mathrm{Hg}$ (II) or $\mathrm{Me}^{203} \mathrm{Hg}$ for $7 \mathrm{~d}$, as described above. Radioisotope additions were 0.617 and $0.123 \mathrm{kBq} \mathrm{l^{-1 }}$ for ${ }^{203} \mathrm{Hg}(\mathrm{II})$ and $\mathrm{Me}^{203} \mathrm{Hg}$, respectively (in 31 seawater). Each day, the fish were exposed to radioactive water for $4 \mathrm{~h}$ before they were removed 
and placed in non-radioactive water and fed with shrimp meat. In the food exposure treatment, 10 fish were placed in 31 seawater and fed radiolabeled brine shrimp for $4 \mathrm{~h}$ each day before being returned to nonradioactive water and fed with shrimp meat. The radioactivity of all fish was assayed, and 2 individuals were immediately dissected to determine the distribution of metals in their different body parts (gills, viscera, and tissues). The remaining 8 fish were rinsed with filtered non-radioactive water, and the radioactivity of each individual was measured immediately. They were subsequently depurated in natural seawater (10 l) for $28 \mathrm{~d}$. The seawater was renewed on a daily basis, and the fish were fed with frozen shrimp meat twice a day. The radioactivity in these individuals was measured at frequent time intervals (every 1 to $3 \mathrm{~d}$ ). At the end of the elimination period, all fish were dissected to determine the distribution of metals in the gill, viscera, head, and tissues.

Modeling exposure and food-chain transfer. Under steady-state conditions, $\mathrm{Hg}$ and $\mathrm{MeHg}$ accumulation in fishes can be calculated by the following equation (Thomann 1981, Wang \& Fisher 1999):

$$
C_{\mathrm{ss}}=\left(k_{\mathrm{u}} \times C_{\mathrm{w}}\right) / k_{\mathrm{ew}}+\left(A E \times I R \times C_{\mathrm{f}}\right) / k_{\mathrm{ef}}
$$

where $C_{\mathrm{ss}}$ is the $\mathrm{Hg}$ or $\mathrm{MeHg}$ concentration in the fish $\left(\mu \mathrm{g} \mathrm{g}^{-1}\right), k_{\mathrm{u}}$ is the metal net-uptake rate-constant from the aqueous phase $\left(\mathrm{l} \mathrm{g}^{-1} \mathrm{~d}^{-1}\right), C_{\mathrm{w}}$ is the metal concentration in the dissolved phase $\left(\mu \mathrm{g} \mathrm{l}^{-1}\right), k_{\mathrm{ew}}$ is the elimination-rate constant following uptake from the dissolved phase $\left(\mathrm{d}^{-1}\right), A E$ is the metal-assimilation

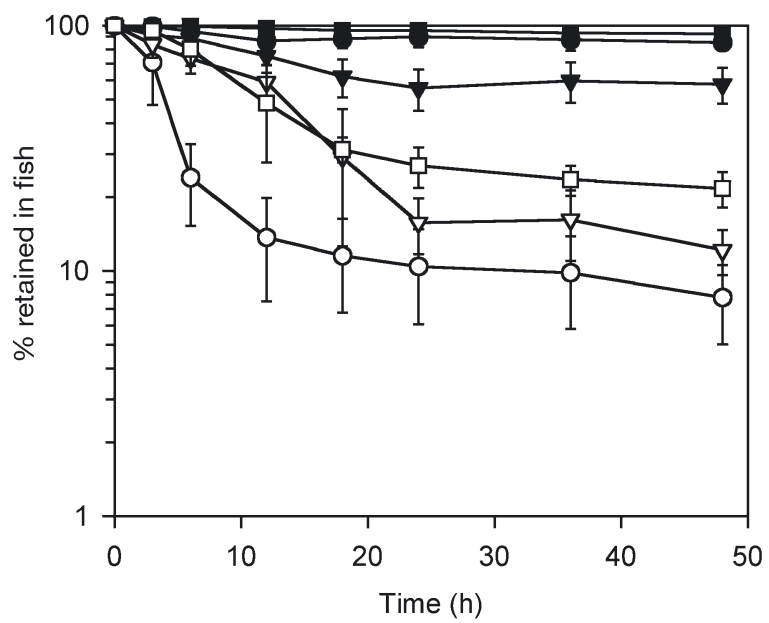

Fig. 1. Plectorhinchus gibbosus. Retention of $\mathrm{Hg}$ (II) and $\mathrm{MeHg}$ following pulse ingestion of different radiolabeled prey. (O) $\mathrm{Hg}$ (II) bound to Artemia sp.; (๑) MeHg bound to Artemia sp.; $(\nabla) \mathrm{Hg}(\mathrm{II})$ bound to fish prey; $(\boldsymbol{\nabla}) \mathrm{MeHg}$ bound to fish prey; ( $\square$ ) $\mathrm{Hg}$ (II) bound to copepod Acartia spinicauda; (匹) $\mathrm{MeHg}$ bound to copepod A. spinicauda. Values are means $\pm \operatorname{SD}(n=7)$ efficiency, $I R$ is the fish feeding rate (in fraction of body weight $\left.\mathrm{d}^{-1}\right), C_{\mathrm{f}}$ is the metal concentration in the ingested prey $\left(\mu \mathrm{g} \mathrm{g}^{-1}\right)$, and $k_{\mathrm{ef}}$ is the elimination-rate constant following uptake from food $\left(\mathrm{d}^{-1}\right)$. The growthrate constant was ignored in the calculation.

Assuming that $C_{\mathrm{f}}$ can be predicted based on the bioconcentration factor of metals $(B C F$, under assumption of equilibrium) in the prey and on $C_{\mathrm{w}}\left(C_{\mathrm{f}}=B C F \times C_{\mathrm{w}}\right)$, the fraction of $\mathrm{Hg}$ or $\mathrm{MeHg}(f)$ coming from the aqueous phase can be calculated from Eq. (1) (Wang \& Fisher 1999):

$$
f=\left[\left(k_{\mathrm{u}} / k_{\mathrm{ew}}\right)\right] /\left[(A E \times I R \times B C F) / k_{\mathrm{ef}}+\left(k_{\mathrm{u}} / k_{\mathrm{ew}}\right)\right]
$$

To predict the fraction of total Hg accumulation arising from $\mathrm{Hg}(\mathrm{II})$ or $\mathrm{MeHg}$, we first calculated the concentration factor $(C F)$ of both $\mathrm{Hg}$ species using Eq. (1):

$$
C F=k_{\mathrm{u}} / k_{\mathrm{ew}}+(A E \times I R \times B C F) / k_{\mathrm{ef}}
$$

Thus, the fraction of total $\mathrm{Hg}$ in the fish due to accumulation from $\mathrm{Hg}(\mathrm{II})(R)$ can be calculated as (Wang et al. 1998, Wang \& Fisher 1999):

$$
R=C F_{\mathrm{Hg}} /\left[C F_{\mathrm{Hg}}+\left(C F_{\mathrm{MeHg}} \times C_{\mathrm{MeHg}} / C_{\mathrm{Hg}}\right)\right]
$$

where $C F_{\mathrm{Hg}}$ is the concentration factor of $\mathrm{Hg}(\mathrm{II})$ in fish, $C F_{\mathrm{MeHg}}$ is the concentration factor of $\mathrm{MeHg}$, and $C_{\mathrm{MeHg}} / C_{\mathrm{Hg}}$ is the ratio of $\mathrm{MeHg}$ concentration to $\mathrm{Hg}$ (II) concentration in water.

The food-chain transfer factor $(T T F)$, or the ratio of metal concentration in fish to metal concentration in prey, can be calculated as (Reinfelder et al. 1998, Wang \& Fisher 1999):

$$
T T F=(A E \times I R) / k_{\mathrm{ef}}
$$

\section{RESULTS}

\section{Assimilation of $\mathrm{Hg}(\mathrm{II})$ and $\mathrm{MeHg}$}

Retention of ingested $\mathrm{Hg}$ (II) and $\mathrm{MeHg}$ by the fish following short-term pulse radioactive feeding is shown in Fig. 1. Significant depuration of ingested $\mathrm{Hg}(\mathrm{II})$ occurred during first day of depuration, whereas there was very little loss of MeHg over the $2 \mathrm{~d}$ depuration period. MeHg associated with both

Table 1. Plectorhinchus gibbosus. Calculated assimilation efficiency mean $\pm \mathrm{SD}(\mathrm{n}=5)$ of $\mathrm{Hg}(\mathrm{II})$ and $\mathrm{MeHg}$ by sweetlips feeding on different prey

\begin{tabular}{|lcc|}
\hline Prey & $\mathrm{Hg}(\mathrm{II})$ & $\mathrm{MeHg}$ \\
\hline Brine shrimp Artemia sp. & $10.4 \pm 4.4$ & $89.8 \pm 8.2$ \\
Copepod Acartia spinicauda & $26.9 \pm 5.1$ & $95.4 \pm 1.2$ \\
Silveside Atherion elymus & $15.8 \pm 4.0$ & $55.6 \pm 10.7$ \\
\hline
\end{tabular}




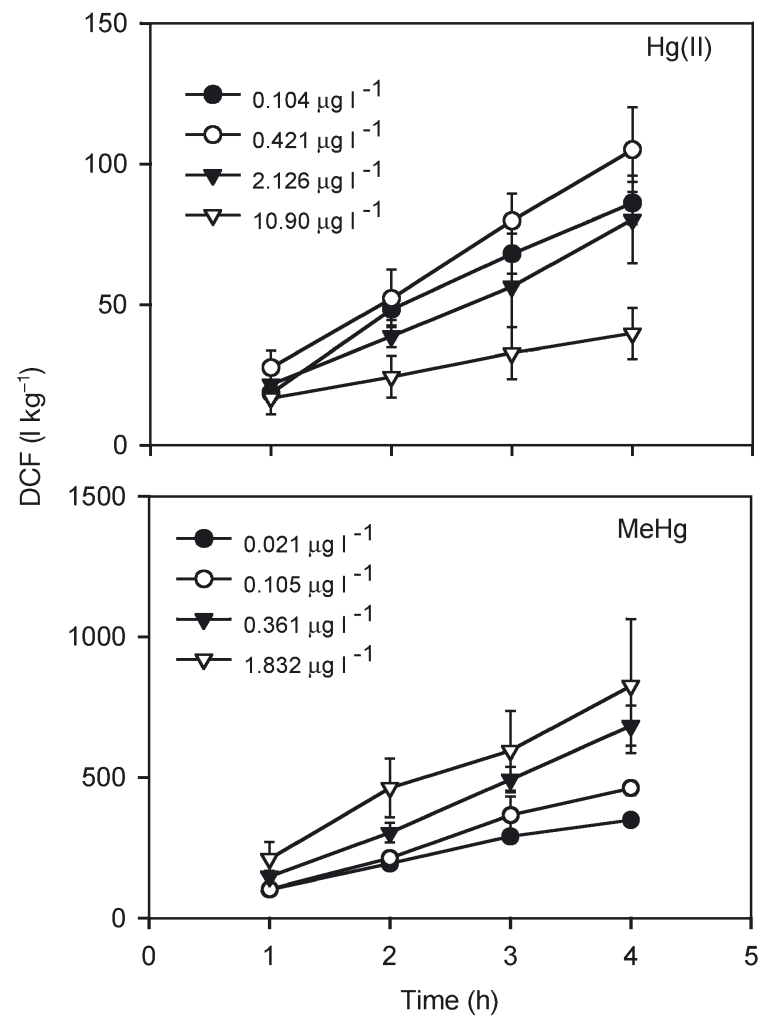

Fig. 2. Plectorhinchus gibbosus. Calculated dry weight concentration factors (DCF) of $\mathrm{Hg}$ (II) and $\mathrm{MeHg}$ as a function of exposure time at different dissolved concentrations. Values are means $\pm \mathrm{SD}(\mathrm{n}=3)$

brine shrimp and copepods was retained very efficiently by the fish over the $2 \mathrm{~d}$ period. Because there was little further loss of either $\mathrm{Hg}(\mathrm{II})$ or $\mathrm{MeHg}$ after $24 \mathrm{~h}$ depuration, the assimilation efficiency $(A E)$ was calculated as the percentage of metal retained in the fish after $24 \mathrm{~h}$ (Table 1). AE ranged between 10 and $27 \%$ for $\mathrm{Hg}(\mathrm{II})$ and between 56 and $95 \%$ for $\mathrm{MeHg}$. In general, both $\mathrm{Hg}(\mathrm{II})$ and $\mathrm{MeHg}$ associated with the copepods were assimilated by the fish at a higher efficiency than when associated with brine shrimp or silverside prey.

In the prey-density experiment, the ingestion rate of the fish on copepods varied considerably among different experimental individuals, even within the same density treatment. It was therefore not possible to calculate the $A E$ for each food-density treatment. Instead, $A E$ was calculated for each individual fish at each specific ingestion rate. The calculated ingestion rate of the fish ranged from 0.2 to $10.3 \%$ of their tissue dry weight each day. The measured $A E$ of $\mathrm{Hg}$ (II) among the different individuals was 8 to $30 \%$. There was no significant relationship between $A E$ and the ingestion rate of fish when all individuals were considered (data not shown), suggesting that the $A E$ of $H g(I I)$ did not vary significantly over the ingestion-rate range quantified in this study (0.2 to $10.3 \%$ ).

\section{Uptake of $\mathrm{Hg}(\mathrm{II})$ and $\mathrm{MeHg}$ from aqueous phase}

Between 1 and $4 \mathrm{~h}$ of exposure, the quantified dry weight concentration factor $(D C F$, radioactivity in fish divided by radioactivity in the water) exhibited an approximately linear uptake pattern. There was however a significant difference in the calculated $D C F$ among the 4 experimental concentrations. A much lower uptake of $\mathrm{Hg}(\mathrm{II})$ was documented with increasing $\mathrm{Hg}$ (II) concentration, whereas uptake of $\mathrm{MeHg}$ increased with increasing $\mathrm{MeHg}$ concentration (Fig. 2). By the end of the exposure period, the $D C F$ of $\mathrm{Hg}$ (II) at the highest concentration $\left(10.90 \mu \mathrm{g} \mathrm{l}^{-1}\right)$ was 2.64 times lower than that at $0.421 \mu \mathrm{g} \mathrm{l}^{-1}$, whereas the DCF of MeHg(II) at the highest concentration $(1.832 \mu \mathrm{g}$ $\mathrm{l}^{-1}$ ) was 2.4 times higher than that at the lowest concentration $\left(0.021 \mathrm{\mu g} \mathrm{l}^{-1}\right)$. After $4 \mathrm{~h}$, the $D C F$ of $\mathrm{MeHg}$ was much higher than the uptake of $\mathrm{Hg}$ (II) at all concentrations.

The calculated uptake-rate at different ambient concentrations is shown in Fig. 3. There was a log-log

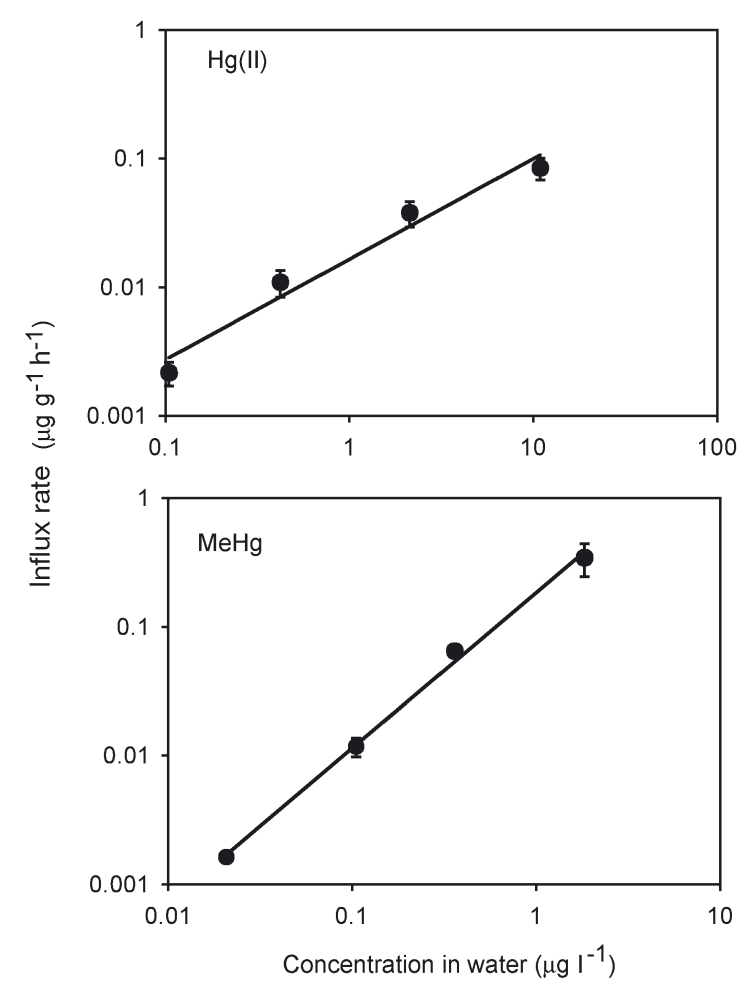

Fig. 3. Plectorhinchus gibbosus. Calculated uptake-rate of $\mathrm{Hg}(\mathrm{II})$ and $\mathrm{MeHg}$ at different dissolved concentrations. Values are means $\pm \operatorname{SD}(n=3)$ 

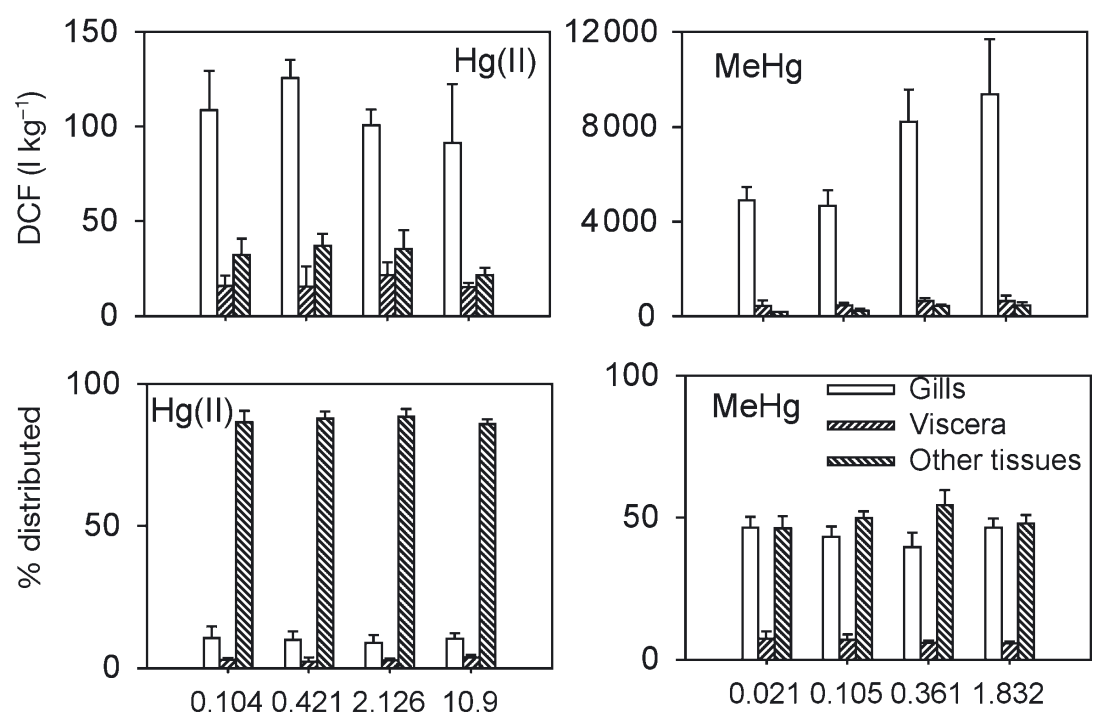

\section{Concentration in water $\left(\mu \mathrm{g} \mathrm{I}^{-1}\right)$}

Fig. 4. Plectorhinchus gibbosus. Calculated dry weight concentration factors $(D C F)$ and distribution of $\mathrm{Hg}(\mathrm{II})$ and $\mathrm{MeHg}$ in different tissues after $4 \mathrm{~h}$ exposure to different dissolved concentrations. Values are means $\pm \operatorname{SD}(n=3)$

linear relationship between the uptake-rate and the ambient dissolved concentrations. The $b$ coefficient of this relationship was 0.781 for $\mathrm{Hg}$ (II) and 1.210 for $\mathrm{MeHg}$. Because the $b$ coefficients deviated from 1.0, we calculated the uptake-rate constant by direct linear regression between uptake-rate and dissolved concentration without log-log transformation, with the assumption of a zero intercept. Thus, the uptake-rate constant of $\mathrm{Hg}$ (II) was $0.195 \mathrm{~g} \mathrm{~g}^{-1} \mathrm{~d}^{-1}$, and was 23.1 times lower than the uptake-rate constant of $\mathrm{MeHg}\left(4.515 \mathrm{~g}^{-1} \mathrm{~d}^{-1}\right)$. By the end of the $4 \mathrm{~h}$ exposure period, $\mathrm{Hg}$ (II) and $\mathrm{MeHg}$ were also distributed differently in the fish tissues (Fig. 4). Most of the accumulated $\mathrm{Hg}$ (II) (86 to $89 \%$ ) was in the tissues, with only a small proportion in the gills and the viscera. In contrast, 43 to $46 \%$ of $\mathrm{MeHg}$ was distributed in the gills and 46 to $55 \%$ in tissues. There was little difference in the distribution among the different concentration treatments. The calculated DCF was highest for the gills (Fig. 4). The DCF of $\mathrm{Hg}$ (II) in tissues was 1.4 to 2.4 times higher than that in the viscera, whereas the DCF of MeHg in tissues was 1.4 to 2.6 times lower than that in the viscera. The DCFs of MeHg in the gills were somewhat higher at the 2 highest concentrations.

\section{Elimination of $\mathrm{Hg}(\mathrm{II})$ and $\mathrm{MeHg}$}

The elimination of radioisotopes from the fish following $7 \mathrm{~d}$ exposure to dissolved or dietary $\mathrm{Hg}$ (II) and MeHg is shown in Fig. 5. Over the 28 d elimination period, only $20 \%$ of the accumulated $\mathrm{MeHg}$ was lost by the fish, whereas 73 to $81 \%$ of the accumulated $\mathrm{Hg}$ (II) was lost from the fish. There was little difference in the loss of accumulated $\mathrm{MeHg}$ between aqueous and dietary uptake. Hg(II) was retained more efficiently when accumulated from the aqueous phase than when accumulated from the dietary phase. Depuration can be approximately modeled by a 2 step loss, first during a $7 \mathrm{~d}$ depuration period and then during a 9 to $28 \mathrm{~d}$ depuration period. The calculated efflux-rate constant (the loss between the 9th and 28th day of depuration) and the biological retention half-lives are shown in Table 2. Thus, $\mathrm{MeHg}$ was lost at a much lower rate $(0.0103$ to $0.0129 \mathrm{~d}^{-1}$ ) than $\mathrm{Hg}$ (II) (0.0287 to $\left.0.0548 \mathrm{~d}^{-1}\right)$ by the fish. $\mathrm{Hg}(\mathrm{II})$ associated with the dietary source was lost 1.9 times faster than the $\mathrm{Hg}$ (II) associated with the aqueous source.

After 7 d exposure, about 4 to 17,5 to 40 , and 55 to $78 \%$ of both $\mathrm{Hg}$ species was distributed in the gills, viscera and tissues, respectively (Fig. 6). Much higher fractions of $\mathrm{Hg}$ (II) and $\mathrm{MeHg}$ were found in the viscera

Table 2. Plectorhinchus gibbosus. Compartmental analysis of elimination mean $\pm \mathrm{SD}$, (n = 8) of $\mathrm{Hg}(\mathrm{II})$ and $\mathrm{MeHg}$ following exposure to dietary and aqueous metals for $7 \mathrm{~d}$. \%: percent of mercury in compartment; $k$ : elimination-rate constant; $t_{1 / 2}$ : biological retention half-lives

\begin{tabular}{|c|c|c|c|c|c|}
\hline \multirow{2}{*}{\multicolumn{2}{|c|}{ Compartment }} & \multicolumn{2}{|c|}{$\mathrm{Hg}(\mathrm{II})$} & \multicolumn{2}{|c|}{$\mathrm{MeHg}$} \\
\hline & & Water & Food & Water & Food \\
\hline $1(0-7 d)$ & $\begin{array}{l}\% \\
k\left(\mathrm{~d}^{-1}\right) \\
t_{1 / 2}(\mathrm{~d})\end{array}$ & $\begin{aligned} 59.2 & \pm 16.2 \\
0.0722 & \pm 0.0066 \\
9.67 & \pm 0.89\end{aligned}$ & $\begin{aligned} 65.3 & \pm 18.0 \\
0.0957 & \pm 0.0179 \\
7.51 & \pm 1.52\end{aligned}$ & $\begin{aligned} 2.2 & \pm 5.0 \\
0.0096 & \pm 0.0062 \\
40.2 & \pm 69.9\end{aligned}$ & $\begin{aligned} 11.1 & \pm 5.1 \\
0.0116 & \pm 0.0059 \\
72.8 & \pm 27.4\end{aligned}$ \\
\hline $2(9-28 d)$ & $\begin{array}{l}\% \\
k\left(\mathrm{~d}^{-1}\right) \\
t_{1 / 2}(\mathrm{~d})\end{array}$ & $\begin{aligned} 38.8 & \pm 16.0 \\
0.0287 & \pm 0.0071 \\
25.4 & \pm 4.9\end{aligned}$ & $\begin{aligned} 36.2 & \pm 12.2 \\
0.0547 & \pm 0.0093 \\
13.1 & \pm 2.45\end{aligned}$ & $\begin{aligned} 97.8 & \pm 5.6 \\
0.0129 & \pm 0.0026 \\
55.7 & \pm 9.5\end{aligned}$ & $\begin{aligned} 89.5 & \pm 5.0 \\
0.0103 & \pm 0.0020 \\
69.8 & \pm 13.4\end{aligned}$ \\
\hline
\end{tabular}




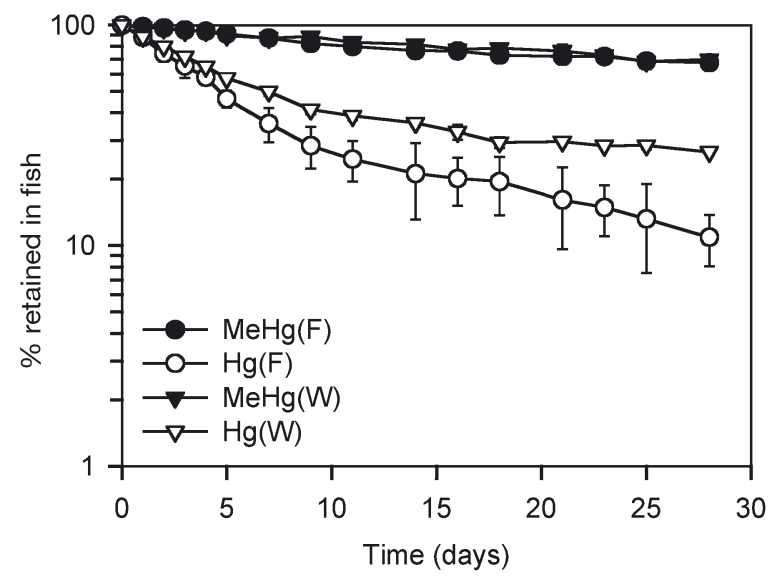

Fig. 5. Plectorhinchus gibbosus. Elimination of $\mathrm{Hg}(\mathrm{II})$ and $\mathrm{MeHg}$ following $7 \mathrm{~d}$ exposure to aqueous (W) or dietary (F) $\mathrm{Hg}(\mathrm{II})$ and $\mathrm{MeHg}$. Values are means $\pm \mathrm{SD}(\mathrm{n}=8)$

when accumulated from the dietary source than when accumulated from the aqueous phase. After $28 \mathrm{~d}$ elimination, the distribution of $\mathrm{Hg}(\mathrm{II})$ and $\mathrm{MeHg}$ in the head was also examined. Only a small percentage of both mercury species was found in the gills $(<6 \%)$; about 8 to $18 \%$ of the metal was in the viscera, and most was distributed in tissues. About 14 to $18 \%$ of $\mathrm{MeHg}$ was found in the head, whereas no Hg(II) was detected in the head.

\section{Modeling exposure and trophic transfer}

Modeling analysis of the exposure and trophic transfer factor of $\mathrm{Hg}$ and $\mathrm{MeHg}$ in fishes requires measurements of several of the parameters in Eq. (1), including $A E, k_{\mathrm{u}}, k_{\mathrm{ew}}, k_{\mathrm{ef},}, I R$ and $B C F$ of $\mathrm{Hg}(\mathrm{II})$ and $\mathrm{MeHg}$ in the prey. Values of $A E, k_{\mathrm{u}}, k_{\mathrm{ew}}$ and $k_{\mathrm{ef}}$ have been taken from this study (Table 3 ). In our calculations we used a single mean value for these parameters, because we did not examine their variability under diverse envi-

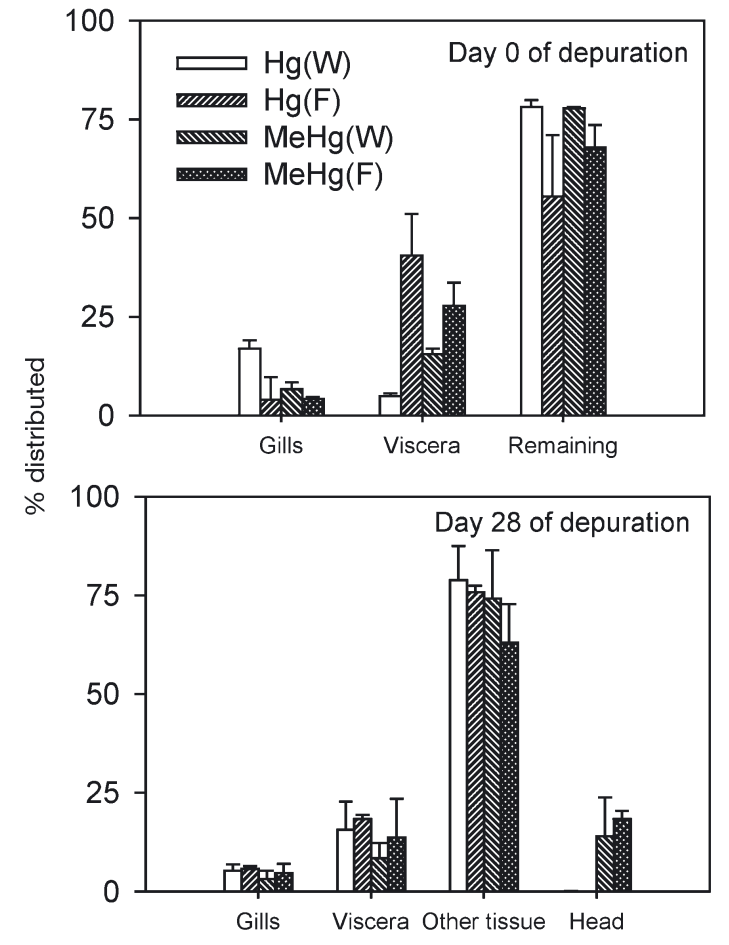

Fig. 6. Plectorhinchus gibbosus. Distribution of $\mathrm{Hg}(\mathrm{II})$ and $\mathrm{MeHg}$ following $7 \mathrm{~d}$ exposure to aqueous (W) or dietary (F) $\mathrm{Hg}(\mathrm{II})$ and $\mathrm{MeHg}$ (Day 0) and after $28 \mathrm{~d}$ elimination (Day 28). Values are means $\pm \mathrm{SD}$ ( $\mathrm{n}=2$ for Day 0, and 4 for Day 28)

ronmental conditions (except for $A E$, which was within a relatively narrow range for different prey types and at different prey densities). Instead, we modeled the exposure of metals within a range of $I R$ and $B C F$ because these 2 parameters vary greatly under natural conditions and we are less certain about them. A range of IR ( 1 to $10 \%$ of body weight per day) (GarnierLaplace et al. 2000) and BCF for both $\mathrm{Hg}$ (II) (2000 to 200000 ) and $\mathrm{MeHg}$ (5000 to 500000 ) (ranging over 2 orders of magnitude) was used in the analysis. The range of $B C F$ for both invertebrate and fish prey was

Table 3. Plectorhinchus gibbosus. Parameters used in modeling exposure of $\mathrm{Hg}$ (II) and MeHg. Assimilation efficiency calculated as \% metal retained. Numbers in parentheses: mean of bioconcentration factor

\begin{tabular}{|lccl|}
\hline Parameter & $\mathrm{Hg}(\mathrm{II})$ & $\mathrm{MeHg}$ & Source \\
\hline Assimilation efficiency $(A E, \%)$ & 20 & 80 & This study \\
Ingestion rate $\left(I R\right.$, in $\%$ body weight $\left.\mathrm{d}^{-1}\right)$ & $0.01-0.1$ & $0.01-0.1$ & Garnier-Laplace et al. (2000) \\
Bioconcentration factor in prey $($ includes copepods and & $2000-200000$ & $5000-500000$ & IAEA (2000) \\
fishes; $\left.B C F, l \mathrm{~kg}^{-1}\right)$ & $(20000)$ & $(50000)$ & This study \\
Uptake rate constant $\left(k_{\mathrm{u}}\right.$, in $\left.\mathrm{l} \mathrm{g}^{-1} \mathrm{~d}^{-1}\right)$ & 0.195 & 4.515 & This study \\
Elimination rate constant from water $\left(k_{\mathrm{ew}}\right.$, in $\left.^{-1}\right)$ & 0.0287 & 0.0129 & This study \\
Elimination rate constant from food $\left(k_{\mathrm{ef}}\right.$, in $\left.^{-1}\right)$ & 0.0547 & 0.0103 & \\
\hline
\end{tabular}




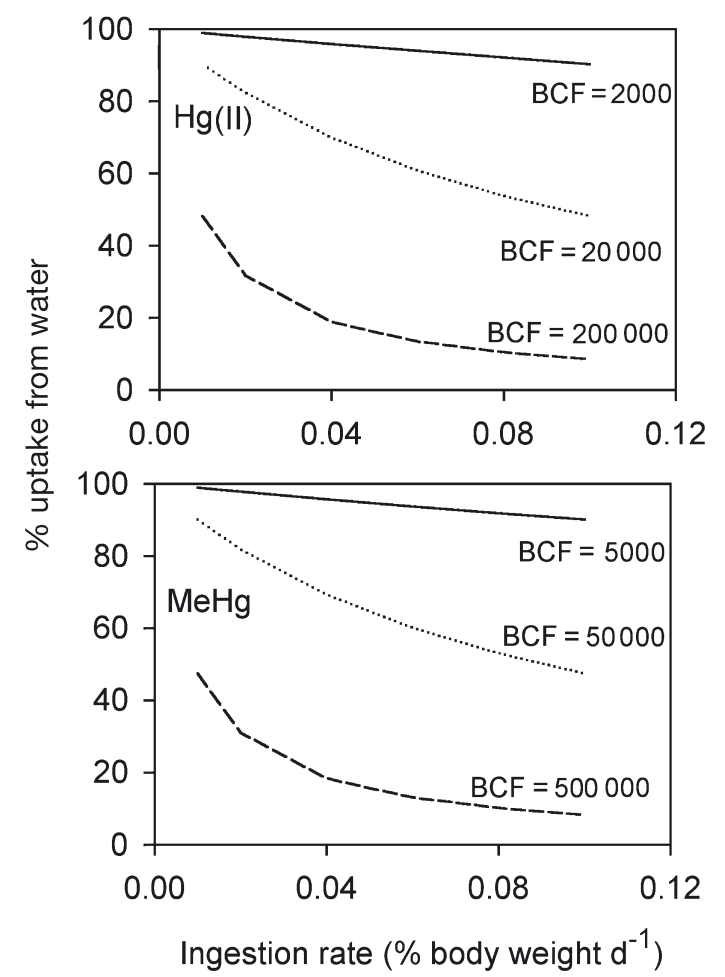

Fig. 7. Plectorhinchus gibbosus. Model-predicted percentage of $\mathrm{Hg}(\mathrm{II})$ and $\mathrm{MeHg}$ uptake from aqueous phase as a function of ingestion rate. $B C F$ : bioconcentration factor in prey $\left(\mathrm{kg}^{-1}\right)$

taken from the literature (IAEA 2000). Our calculation, using Eq. (2), indicates that the relative importance of dissolved vs diet uptake varies greatly at different $I R \mathrm{~s}$ and $B C F \mathrm{~S}$ for both species of mercury (Fig. 7). At the low end of $B C F$ (2000 for $\mathrm{Hg}[\mathrm{II}]$ and 5000 for $\mathrm{MeHg}$ ), uptake is dominated by the aqueous phase, irrespective of the change in $I R$. At the high end of $B C F$

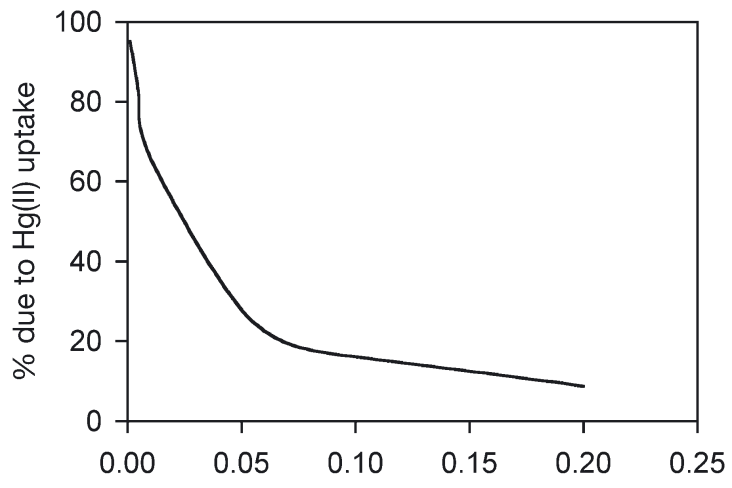

Relative concentration of $\mathrm{MeHg}$ to $\mathrm{Hg}(\mathrm{II})$ in water

Fig. 8. Plectorhinchus gibbosus. Model-predicted percentage of contribution of $\mathrm{Hg}$ (II) to overall $\mathrm{Hg}$ accumulation as a function of relative concentration of dissolved $\mathrm{MeHg}$ to dissolved $\mathrm{Hg}(\mathrm{II})$ in seawater
(200000 for $\mathrm{Hg}[\mathrm{II}]$ and 500000 for $\mathrm{MeHg}$ ), dietary uptake dominates the accumulation of both $\mathrm{Hg}$ (II) and $\mathrm{MeHg}(>50 \%)$.

To further model the relative importance of $\mathrm{Hg}$ (II) and $\mathrm{MeHg}$ species in the overall $\mathrm{Hg}$ bioaccumulation in the fish, we used the mean values of $A E, k_{\mathrm{u}}, k_{\mathrm{ew}}, k_{\mathrm{ef}}$, and $B C F$ for both $\mathrm{Hg}(\mathrm{II})$ and $\mathrm{MeHg}$ in our calculations (Table 3; Eq. 4). Variation in IR will have little influence, because uptake from both $\mathrm{Hg}(\mathrm{II})$ and $\mathrm{MeHg}$ depends on IR. Methylation of inorganic $\mathrm{Hg}$ in the water column is possible (Topping \& Davies 1981). Generally, MeHg comprises a small fraction of the total $\mathrm{Hg}$ in oxic aquatic environments. Kannan et al. (1998) found that $\mathrm{MeHg}$ accounted for 0.03 to $52 \%$ of the total $\mathrm{Hg}$ in canals and creeks that discharged into the Florida Bay. Fitzgerald \& Mason (1997) indicated that MeHg concentration in the Patuxent River was about $10 \%$ of the total $\mathrm{Hg}$ concentration. We therefore modeled the likely contribution of $\mathrm{Hg}$ (II) accumulation with a dissolved $\mathrm{MeHg}$ to $\mathrm{Hg}$ (II) concentration ratio of 0.001 to $20 \%$ (Fig. 8). Thus, about 16 to $95 \%$ of total $\mathrm{Hg}$ in the fish may have been due to the uptake of $\mathrm{Hg}$ (II).

The potential trophic transfer factor of both $\mathrm{Hg}$ (II) and $\mathrm{MeHg}$ was modeled using Eq. (5), assuming a range of $I R$ for the fish (Fig. 9). The calculation shows that $\mathrm{Hg}$ (II) is unlikely to be biomagnified due to the rel-

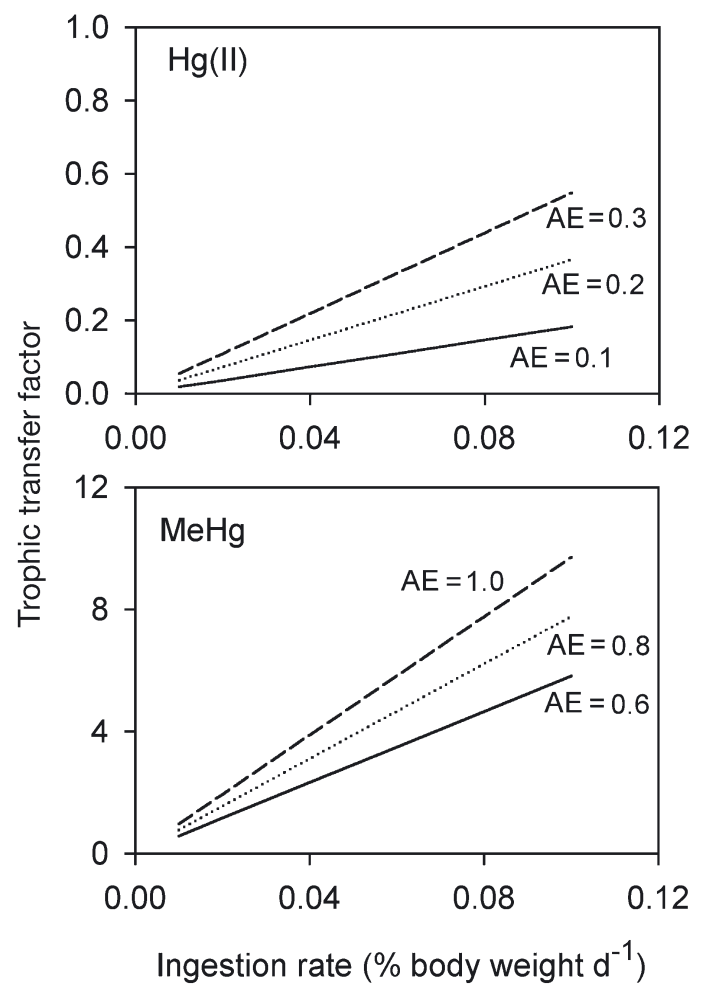

Fig. 9. Plectorhinchus gibbosus. Model-predicted food-chain transfer factor of $\mathrm{Hg}$ (II) and $\mathrm{MeHg}$ as a function of ingestion rate. $A E$ : assimilation efficiency 
atively low $A E$ as well as the relatively high elimination-rate constant. The highest potential TTF of $\mathrm{Hg}$ (II) in the fish is about 0.6 using the highest $A E$ and $I R$. In contrast, the TTF for $\mathrm{MeHg}$ is $>1$ and $<10$ under conditions likely to be encountered by the fish.

\section{DISCUSSION}

The assimilation efficiency of $\mathrm{Hg}(\mathrm{II})$ and $\mathrm{MeHg}$ measured in the marine sweetlips Plectorhinchus gibbosus was quite comparable to that in previous studies on other fishes (Pentreath 1976a, Mason 2002). MeHg appears to be very efficiently assimilated by fishes from dietary sources, with an $A E$ of $>56 \%$ in our study, although some earlier studies only found an $A E$ of $20 \%$ in freshwater fishes (Ribeyre \& Boudou 1984, Boudou \& Ribeyre 1997). The $A E$ of $\mathrm{MeHg}$ was 3.5 to 8.6 times higher than that of $\mathrm{Hg}$ (II) for sweetlips feeding on 3 different prey species. The high assimilation of $\mathrm{MeHg}$ by this fish may have been due to the lipophilicity of this compound and/or the digestive physiology of the sweetlips. Mason (2002) proposed the likelihood of rapid desorption of $\mathrm{MeHg}$ within the digestive fluids of animals leading to a much higher assimilation. Digestive fluid desorption may control the assimilation of metals such as $\mathrm{Cd}$, whereas for other metals, these 2 processes (desorption and assimilation) are likely to be decoupled (Wang et al. 2002, Yan \& Wang 2002). Lawson \& Mason (1998) suggested that fishes feeding on copepods assimilate $\mathrm{MeHg}$ more efficiently than $\mathrm{Hg}(\mathrm{II})$, as they found a larger fraction of $\mathrm{MeHg}$ in the soft tissues of the copepods. Ni et al. (2000) however did not find any relationship between the $A E$ of $\mathrm{Cd}, \mathrm{Cr}$, and $\mathrm{Zn}$ in mudskippers Periophthalmus cantonensis and glassy fish Ambassis urotaenia and their distribution in the soft tissues of the copepod prey. The difference in trophic transfer between $\mathrm{Hg}$ (II) and MeHg may also be caused by their differential partitioning in phytoplankton cells (e.g. surface-bound and cytoplasm-bound); thus, speciation and uptake at the base of marine foodchains are critical for the food chain transfer of these 2 mercury species (Mason et al. 1995).

In our experiments, both mercury species associated with the copepods were generally assimilated at a higher efficiency than those associated with brine shrimp and silversides. Among the many elements studied so far, the $A E$ of $\mathrm{MeHg}$ and radiocesium in fishes are the highest (Ni et al. 2000, Zhao et al. 2001, Baines et al. 2002, Xu \& Wang 2002). For example, the $A E$ of radiocesium range between 78 and $95 \%$ in the marine mangrove snappers Lutjanus argentimaculatus (Zhao et al. 2001). Such a high $A E$ from a dietary prey source contributes greatly to the potential biomagnification of these 2 compounds in marine predatory fishes.
Few studies have examined the influence of various food conditions on the assimilation of metals by fishes (Xu \& Wang 2002). In our study, a range of typical ingestion rates $(0.2$ to $11 \%)$ of marine fish in natural environment had no significant influence on their $A E$ of $\mathrm{Hg}(\mathrm{II})$, presumably because of the relatively low range of ingestion rates examined. The sweetlip fish appears to process the ingested dietary Hg comparably in different feeding conditions. In a previous study, we found that the $A E$ of $\mathrm{Cd}$, Se, and $\mathrm{Zn}$ decreased significantly with increasing ingestion rate of the fish, but at a much higher $I R\left(>28 \%\right.$ of body weight $\mathrm{d}^{-1}$ ) than found in this study (Xu \& Wang 2002). At the 2 lower IRs examined by Xu \& Wang (2002) (5 to $7 \%$ of body weight $\mathrm{d}^{-1}$ ), there was no major difference in the $A E$ of these metals. Because the $A E$ of $\mathrm{Hg}$ (II) was fairly independent of the feeding rate under typical conditions, the uptake-rate constant for dietary sources (a combination of $A E$ and $I R$ ) would be expected to increase proportionally with increasing $I R$.

The uptake of both $\mathrm{Hg}$ species was linear over time of exposure at a relatively constant dissolved concentration, generally agreeing with earlier studies (Pentreath 1976a, Ribeyre \& Boudou 1984). The uptakerate exhibited a log-log relationship with the dissolved concentration for both $\mathrm{Hg}$ species, indicating that uptake was primarily a Freundlich absorption type dominated by passive diffusion or a facilitated transport process (Golding et al. 2002). Whether the dissolved uptake is active, however, cannot be concluded from this study. We calculated a $b$ coefficient of the power relationship between uptake-rate and dissolved concentration of 1.21 for $\mathrm{MeHg}$ and 0.761 for $\mathrm{Hg}$, suggesting that the uptake of $\mathrm{MeHg}$ increased whereas the uptake of $\mathrm{Hg}$ (II) decreased disproportionally with increasing dissolved concentration. Accordingly, a higher MeHg concentration resulted in a higher DCF in the fish, whereas the DCF of $\mathrm{Hg}$ (II) decreased with increasing $\mathrm{Hg}$ (II) concentration.

The calculated uptake rate constant (with the assumption that uptake is a first-order process) of $\mathrm{MeHg}$ was about 23 times higher than that of $\mathrm{Hg}$ (II). Ribeyre \& Boudou (1984) found that the accumulation of MeHg by the fish Salmo gairdneri was about 6 times greater than the accumulation of $\mathrm{Hg}$ (II) over a $30 \mathrm{~d}$ exposure period. Because both species displayed comparable lipophilicity (Mason et al. 1995, Mason 2002), lipophilicity cannot solely account for the difference in their uptake. As in previous studies (Xu \& Wang 2002), the DCF of the gills in this study was the highest among the different fish parts examined, primarily because the gills were the primary site for metal uptake from the aqueous phase and have a relatively large surface area. A marked difference between $\mathrm{Hg}$ (II) and $\mathrm{MeHg}$ distribution in the tissues was also 
found. MeHg was evenly distributed between the gills and tissues, whereas most $\mathrm{Hg}$ (II) was in the tissues, suggesting that $\mathrm{Hg}$ (II) was in fact rapidly transported to the tissues after being taken up by the gills.

Our elimination rate measurements demonstrated a major difference between the $2 \mathrm{Hg}$ species, with $\mathrm{Hg}$ (II) being lost at a faster rate than $\mathrm{MeHg}$. For comparison, the elimination rate constants $\left(k_{\mathrm{e}}\right)$ in mangrove snappers were $0.025-0.047 \mathrm{~d}^{-1}, 0.020-0.023 \mathrm{~d}^{-1}, 0.027-$ $0.031 \mathrm{~d}^{-1}$, and $0.015 \mathrm{~d}^{-1}$ for $\mathrm{Cd}, \mathrm{Cs}, \mathrm{Se}$, and $\mathrm{Zn}$, respectively (Zhao et al. 2001, Xu \& Wang 2002). Dietary $\mathrm{Hg}$ (II) was lost by the sweetlips about 2 times faster than aqueous $\mathrm{Hg}(\mathrm{II})$, whereas there was no major difference in the elimination between dietary and aqueous MeHg. Consistently, a much higher fraction of dietary $\mathrm{Hg}$ (II) was found in the viscera compared with aqueous $\mathrm{Hg}$ (II) at the end of the exposure pereiod. Digestive processes may have thus facilitated the elimination of ingested $\mathrm{Hg}$ (II) from the sweetlips. Despite the greater distribution of dietary $\mathrm{MeHg}$ in the viscera, there was no major difference in its elimination, implying that the elimination of $\mathrm{MeHg}$ may not necessarily be controlled by the digestive process.

Trudel \& Rasmussen (1997) summarized the elimination rate of $\mathrm{Hg}(\mathrm{II})$ and $\mathrm{MeHg}$ in fishes, mostly freshwater species. They found that the elimination rate of $\mathrm{Hg}$ was highly dependent on several factors, including radiolabeling period, body size and temperature. For example, short-term experiments $(<90 \mathrm{~d})$ overestimated the elimination rate of mercury, and $\mathrm{Hg}$ (II) was excreted 3 times faster than $\mathrm{MeHg}$. We radiolabeled both Hg species for $7 \mathrm{~d}$, and the elimination rate was quantified using the radiotracer technique. Whether the elimination rate constant determined after a relatively short exposure period overestimates that in nature is unknown. It should be noted that elimination rate measurements quantified under field conditions using stable-metal analysis may underestimate the elimination rate because stable-metal analysis does not necessarily quantify the unidirectional flux of metals across fishes. Trudel \& Rasmussen (1997) further showed that both $\mathrm{Hg}(\mathrm{II})$ and $\mathrm{MeHg}$ excretion are negatively correlated with body size, but that only $\mathrm{MeHg}$ elimination is significantly correlated with water temperature. The $\mathrm{MeHg}$ elimination rate in the present study was independent of mercury burden and concentration, indicating that this is a first-order process. Marine teleost fishes must drink seawater to counteract loss of water from their tissues. Active elimination (as opposed to passive uptake) to remove salt from tissue to seawater against the concentration gradient may have contributed to the higher elimination of metals compared to freshwater fishes.

Using the autoradiography technique, Rouleau et al. (1999) demonstrated the specificity of the accumulation sites of $\mathrm{Hg}(\mathrm{II})$, in which waterborne $\mathrm{Hg}$ was taken up by water-exposed receptor cells of sensory nerves and subsequently transferred to the brain by axonal transport, a normal physiological process for the transport of organelles and dissolved neuronal constituents along nerve axons. After 28 d elimination, we found a significant fraction of $\mathrm{MeHg}$ in the head of sweetlips probably associated with the brain nervous system or fatty tissues. In contrast, no $\mathrm{Hg}$ (II) was found in the head after 28 d elimination. Riisgaard \& Hansen (1990) showed that flounder Platichthys flesus force-fed with contaminated mussels accumulated MeHg in blood cells, liver, kidney and muscle tissues, while $\mathrm{Hg}$ (II) only accumulated in measurable amounts in the liver and kidney.

We used the radiotracer technique to study the biokinetics of $\mathrm{Hg}$ (II) and $\mathrm{MeHg}$ in the sweetlips. Whether there was any biotransformation (methylation and demethylation) within the fish body was not revealed by our study. Pennacchioni et al. (1976) suggested that fishes are unable to methylate $\mathrm{Hg}$ in vivo, whereas other studies indicated that methylation and demethylation are possible (Burrows \& Krenkel 1973, Simon \& Boudou 2001). We found a significant difference in the $A E$, the uptake rate constant, and the elimination rate constant between $\mathrm{Hg}$ (II) and MeHg. There was also a marked difference in the distribution of $\mathrm{Hg}$ (II) and $\mathrm{MeHg}$ in the head of the fish. About 14 to $18 \%$ of $\mathrm{MeHg}$ was detected in the head at the end of the $28 \mathrm{~d}$ elimination period, whereas $\mathrm{Hg}$ (II) in the head was undetectable. Clearly, biotransformation in the tissues of Plectorhinchus gibbosus needs to be further examined.

Our calculation using experimentally derived $A E$ and an elimination rate constant showed a trophic transfer factor (TTF) of <1 for $\mathrm{Hg}(\mathrm{II})$, and $>1$ for $\mathrm{MeHg}$ under all conditions, consistent with the results of numerous field studies on the potential biotransfer of both species of $\mathrm{Hg}$ in marine and freshwater food chains (Hill et al. 1996, Jackson 1998). Our model identified a few important processes responsible for the potential transfer of $\mathrm{Hg}(\mathrm{II})$ and $\mathrm{MeHg}$. Despite the major differences in the $A E$ and in elimination between $\mathrm{MeHg}$ and $\mathrm{Hg}$ (II), the biomagnification of $\mathrm{MeHg}(T T F>1)$ is probably caused principally by very efficient assimilation of the prey, even though the elimination rate constant is consistently low. Similarly, the potential biomagnification of radiocesium with a predicted mean TTF of 2.0 (Zhao et al. 2001) resulted from a very high $A E$, although its elimination rate constant was fairly comparable to that of metals such as Cd, Se, and Zn.

Although most bioaccumulation studies on the biomagnification of MeHg assume the $\mathrm{Hg}$ species is accumulated in fishes mainly in the dietary phase (e.g. by trophic transfer), there is little experimental evidence on the relative importance of aqueous vs dietary uptake under environmentally relevant exposure regimes (Hall et al. 1997). Hall et al. (1997) conducted a field 
experiment exposing the freshwater finescale dace Phoxinus neogaeus to different concentrations of aqueous and dietary MeHg. They provided the first experimental evidence that food was the dominant pathway for $\mathrm{MeHg}$ bioaccumulation in fishes at natural levels of MeHg. In their study, uptake from water made up at most $15 \%$ of the total accumulation of $\mathrm{Hg}$ in the fish. A much earlier study, however, found that dissolved $\mathrm{MeHg}$ in seawater was the critical factor for $\mathrm{MeHg}$ accumulation (Fujiki 1980). Our kinetic model demonstrated that at the high end of the bioconcentration factor $\left(>5 \times 10^{5}\right)$, especially for fish prey, dietary uptake dominates $\mathrm{MeHg}$ accumulation. At the low end of $B C F$ $\left(5 \times 10^{3}\right)$, however, aqueous uptake dominates $\mathrm{MeHg}$ accumulation. It thus appears that the importance of dietary ingestion is strongly related to the type of prey ingested and the feeding rate of the individual fish. In a recent study, dietary $\mathrm{MeHg}$ decreased the reproduction of adult fathead minnows at a dietary concentration encountered by predatory fishes in aqueous systems (Hammerschmidt et al. 2002).

A vast number of studies have shown that the majority of $\mathrm{Hg}$ in fish muscle is in the methylated form (Lasorsa \& Allen 1994, Wagemann et al. 1997), but the percentage of $\mathrm{MeHg}$ in fishes is also highly dependent on the trophic status of the fishes (Kidd et al. 1995, Mason et al. 2000). We are not aware of any previous experimental studies attempting to separate the relative importance of both species of $\mathrm{Hg}$ to the overall $\mathrm{Hg}$ bioaccumulation in marine fish. Our model simulation demonstrates that the relative contribution of the 2 different $\mathrm{Hg}$ species varies as a function of relative concentration of $\mathrm{MeHg}$ in the water. With a low fraction of dissolved $\mathrm{MeHg}$ in the water, $\mathrm{Hg}$ (II) uptake still dominates the overall $\mathrm{Hg}$ accumulation, even though the bioconcentration factor (or uptake rate constant) of $\mathrm{MeHg}$ is much higher than that of $\mathrm{Hg}$ (II). Of course, this calculation assumes that there is no methylation/ demethylation in the fish. It should also be pointed out that we used a mean value of $A E, k_{\mathrm{u}}, k_{\mathrm{ew}}, k_{\mathrm{ef}}$, and $B C F$ in our calculation. Any change in these parameters (particularly in $B C F$ ) could alter the relative contribution of the 2 mercury species. A further challenge will be to verify our modeling prediction on the significance of both species of $\mathrm{Hg}$ to the total Hg accumulation in fishes. Validation of the kinetic model has been conducted for a few marine invertebrates (e.g. Wang et al. 1996, 1998), and it is equally important to validate this model for fishes.

Acknowledgements. We thank the anonymous reviewers for their very constructive comments on this work. This study was supported by a Competitive Earmarked Research Grant from the Hong Kong Research Grants Council (HKUST6108/00M) to W.-X.W.

\section{LITERATURE CITED}

Baines SB, Fisher NS, Stewart R (2002) Assimilation and retention of selenium and other trace elements from crustacean food by juvenile striped bass (Morone saxatilis). Limnol Oceanogr 47:646-655

Bargagli R, Monaci F, Sanchez-Hernandez JC, Cateni D (1998) Biomagnification of mercury in an Antarctic marine coastal food web. Mar Ecol Prog Ser 169:65-76

Barkay T, Gillman M, Turner RR (1997) Effects of dissolved organic carbon and salinity on bioavailability of mercury. Appl Environ Microbiol 63:4267-4271

Boudou A, Ribeyre F (1984) Influence of exposure length on the direct bioaccumulation of 2 mercury compounds by Salmo gairderi (fry) and the relationship between organism weight and mercury concentrations. Water Res 18: 81-86

Boudou A, Ribeyre F (1997) Mercury in the food web: accumulation and transfer mechanisms. Met Ions Biol Syst 34: 289-319

Boudou A, Belnomdedieu M, Georgescauld D, Ribeyre F Saouter E (1991) Fundamental roles of biological barriers in mercury accumulation and transfer in freshwater ecosystems: analysis at organisms, organ, cell and molecular levels. Water Air Soil Pollut 56: 807-822

Bowles KC, Apte SC, Maher WA, Kawei M, Smith R (2001) Bioaccumulation and biomagnification of mercury in Lake Murray, Papua New Guinea. Can J Fish Aquat Sci 58: 888-897

Burrows WD, Krenkel PA (1973) Studies on uptake and loss of methyl mercury by bluegills (Lepomis macrochirus Raf.). Environ Sci Technol 7:1127-1130

Dickman MD, Leung CKM, Leong MKH (1998) Hong Kong male subfertility links to mercury in human hair and fish. Sci Total Environ 214:165-174

Dickman MD, Leung KMC, Koo LCL (1999) Mercury in human hair and fish: is there a Hong Kong male subfertility connection? Mar Pollut Bull 39:352-356

Fitzgerald WF, Mason RP (1997) Biogeochemical cycling of mercury in the marine environment. In: Sigel A, Sigel H (eds) Metal ions in biological systems. Marcel Dekker, New York, p 53-111

Fujiki M (1980) Methylmercury accumulation in plankton and fish. In: Baker RA (ed) Contaminants and sediments, Vol 2 Analysis, chemistry, biology. Ann Arbor Science Publishers, Ann Arbor, MI, p 485-491

Garnier-Laplace J, Adam C, Baudin JP (2000) Experimental kinetic rates of food-chain and waterborne radionuclide transfer to freshwater fish: a basis for the construction of fish contamination charts. Arch Environ Contam Toxicol 39:133-144

Golding GR, Kelly CA, Sparling R, Loewen P, Rudd JWM, Barkay T (2002) Evidence for facilitated uptake of $\mathrm{Hg}$ (II) by Vibrio anguillarum and Escherichia coli under anaerobic and aerobic conditions. Limnol Oceanogr 47:967-975

Hall ED, Bodaly RA, Fudge RJP, Rudd JWM, Rosenberg DM (1997) Food as the dominant pathway of methylmercury uptake by fish. Water Air Soil Pollut 100:13-24

Hammerschmidt CR, Sandheinrich MB, Wiener JG, Rada RG (2002) Effects of dietary methylmercury on reproduction of fathead minnows. Environ Sci Technol 36:877-883

Hill WR, Steward AJ, Napolitano GE (1996) Mercury speciation and bioaccumulation in lotic primary producers and primary consumers. Can J Fish Aquat Sci 53:812-819

Honda $\mathrm{H}$, Ishikawa N, Yamanaka H, Kikuchi T, Amano K (1978) Mercury accumulation in marine fish. J Food Hyg Soc Jpn 19:112-116 
IAEA (International Atomic Energy Agency) (2000) Sediment $\mathrm{k}_{\mathrm{d}} \mathrm{s}$ and concentration factors for radionuclides in the marine environment. IAEA Tech Rep Ser 247

Jackson TA (1998) Mercury in aquatic ecosystems. In: Langston WJ, Bebianno MJ (eds) Metal metabolism in aquatic environments. Chapman \& Hall, London, p 77-158

Joiris CR, Das HK, Holsbeek L (2000) Mercury accumulation and speciation in marine fish from Bangladesh. Mar Pollut Bull 40:454-457

Kannan K, Smith RG, Lee RF, Windom HL, Heitmuller PT, Macauley JM, Summers JK (1998) Distribution of total mercury and methylmercury in water, sediment, and fish from south Florida estuaries. Arch Environ Contam Toxicol 34:109-118

Kidd KA, Hesslein RH, Fudge RJP, Hallard KA (1995) The influence of trophic level as measured by $\delta^{15} \mathrm{~N}$ on mercury concentrations in freshwater organisms. Water Air Soil Pollut 80:1011-1015

Lasorsa B, Allen GS (1994) The methylmercury to total mercury ratio in selected marine, freshwater, and terrestrial organisms. Water Air Soil Pollut 80:905-913

Lawson NM, Mason RP (1998) Accumulation of mercury in estuarine food chains. Biogeochemistry 40:235-247

Leah RT, Evans SJ, Johnson MS, Collings S (1991) Spatial patterns in accumulation of mercury by fish from the NE Irish Sea. Mar Pollut Bull 22:172-175

Mason RP (2002) The bioaccumulation of mercury, methylmercury and other toxic elements into pelagic and benthic organisms. In: Newman MC, Roberts MH JR, Hale RC (eds) Coastal and estuarine risk assessment. Lewis, Boca Raton, p 127-149

Mason RP, Reinfelder KR, Morel FMM (1995) Bioaccumulation of mercury and methylmercury. Water Air Soil Pollut 80:915-921

Mason RP, Laporte JM, Andres S (2000) Factors controlling the bioaccumulation of mercury, methylmercury, arsenic, selenium, and cadmium by freshwater invertebrates and fish. Arch Environ Contam Toxicol 38:283-297

Monteiro LR, Costa V, Furness RW, Santos RS (1996) Mercury concentrations in prey fish indicate enhanced bioaccumulation in mesopelagic environments. Mar Ecol Prog Ser 141:21-25

Morel FMM, Kraepiel AML, Amyot M (1998) The chemical cycle and bioaccumulation of mercury. Annu Rev Ecol Syst 29:543-566

Ni IH, Wang WX, Tam YK (2000) The transfer of Cd, Cr, and Zn from zooplankton to mudskipper and glassy fishes. Mar Ecol Prog Ser 194:203-210

Pennacchioni A, Marchetti R, Gaggino GF (1976) Inability of fish to methylate mercuric chloride in vivo. J Environ Qual 5:451-454

Pentreath RJ (1976a) The accumulation of organic mercury from seawater by the plaice Pleuronectes platessa L. J Exp Mar Biol Ecol 24:121-132

Pentreath RJ (1976b) The accumulation of mercury from food by the plaice Pleuronectes platessa L. J Exp Mar Biol Ecol 25:51-65

Phillips GR, Buhler DR (1978) The relative contribution of methylmercury from food or water to rainbow trout (Salmo gairdneri) in a controlled laboratory environment. Trans Am Fish Soc 107:853-861

Reinfelder JR, Fisher NS, Luoma SN, Nichols JW, Wang WX (1998) Trace element trophic transfer in aquatic organisms: a critique of the kinetic model approach. Sci Total
Environ 219:117-135

Ribeyre F, Boudou A (1984) Bioaccumulation and tissue distribution of mercury-HgCl2 and $\mathrm{MeHgCl}$ in Salmo gairdneri after direct contamination. Water Air Soil Pollut 23: 169-186

Riisgaard HU, Hansen S (1990) Biomagnification of mercury in a marine grazing food chain: algal cells Phaeodactylum tricornutum, mussels Mytilus edulis and flounders Platichthys flesus studied by means of a stepwise reduction-CVAA method. Mar Ecol Prog Ser 62:259-270

Rouleau C, Block M (1997) Fast and high-yield synthesis of radioactive $\mathrm{Me}^{203} \mathrm{Hg}$. Appl Organometall Chem 11: 751-753

Rouleau C, Gobeil C, Tjalve H (1998) Pharmacokinetics and distribution of dietary tributyltin compared to those of methylmercury in the American plaice Hippoglossoides platessoides. Mar Ecol Prog Ser 171:275-284

Rouleau C, Borg-Neczak K, Gottofrey J, Tjalve H (1999) Accumulation of waterborne mercury(II) in specific areas of fish brain. Environ Sci Technol 33:3384-3389

Simon O, Boudou A (2001) Direct and trophic contamination of the herbivorous carp (Ctenopharyngodon idella) by inorganic mercury and methylmercury. Ecotoxicol Environ Saf 50:48-59

Thomann RV (1981) Equilibrium model of the fate of microcontaminants in diverse aquatic food chains. Can J Fish Aquat Sci 38:280-296

Topping G, Davies IM (1981) Methylmercury production in the marine water column. Nature 290:243-244

Trudel R, Rasmussen JB (1997) Modeling the elimination of mercury by fish. Environ Sci Technol 31:1716-1722

Wagemann R, Trebacz E, Hunt R, Boila G (1997) Percent methylmercury and organic mercury in tissues of marine mammals and fish using different experimental and calculation methods. Environ Toxicol Chem 16:1859-1866

Wang WX (2002) Interaction of trace metals and different marine food chains. Mar Ecol Prog Ser 243:295-309

Wang WX, Fisher NS (1999) Delineating metal accumulation pathways for aquatic invertebrates. Sci Total Environ 237/238:459-472

Wang WX, Fisher NS, Luoma SN (1996) Kinetic determinations of trace element bioaccumulation in the mussel Mytilus edulis. Mar Ecol Prog Ser 140:91-113

Wang WX, Griscom SB, Fisher NS (1997) Bioavailability of $\mathrm{Cr}(\mathrm{III})$ and $\mathrm{Cr}(\mathrm{VI})$ to marine mussels from solute and particulate pathways. Environ Sci Technol 31:603-611

Wang WX, Stupakoff I, Gagnon C, Fisher NS (1998) Bioavailability of inorganic and methylmercury to a marine depositfeeding polychaete. Environ Sci Technol 32:2564-2571

Wang WX, Yan Q, Fan W, Xu Y (2002) Bioavailability of sedimentary metals from a contaminated bay. Mar Ecol Prog Ser 240:27-38

Watras CJ, Back RC, Halvorsen S, Hudson RJM, Morrison KA, Wente SP (1998) Bioaccumulation of mercury in pelagic freshwater food webs. Sci Total Environ 219: 183-208

Xu Y, Wang WX (2002) Exposure and food chain transfer factor of $\mathrm{Cd}, \mathrm{Se}$, and $\mathrm{Zn}$ in a marine fish, Lutjanus argentimaculatus. Mar Ecol Prog Ser 238:173-186

Yan QL, Wang WX (2002) Metal exposure and bioavailability to a marine deposit-feeding sipuncula Sipunculus nudus. Environ Sci Technol 36:40-47

Zhao X, Wang WX, Yu KN, Lam PKS (2001) Biomagnification of radiocesium in a top marine fish predator. Mar Ecol Prog Ser 222:227-237

Submitted: March 3, 2003; Accepted: July 22, 2003

Proofs received from author(s): September 23, 2003 